\title{
From psychology to phenomenology (and back again): A controversy over the method in the school of Twardowski
}

\section{Witold Płotka ${ }^{1}$}

Published online: 4 April 2019

(C) The Author(s) 2019

\begin{abstract}
This paper seeks to define the main trends, arguments and problems regarding the question of method formulated by Twardowski and his students. In this regard, the aim of the paper is twofold. First, I situate Brentano's project of descriptive psychology within the context of disputes in the school of Twardowski concerning the method of both psychology and phenomenology, arguing that descriptive-psychological analysis was dominant in this respect. Second, the study explores the notion of eidetic phenomenology, as founded on a methodological procedure, which supposed to guarantee infallibility of its descriptions. To show this, I first reconstruct Brentano's concept of descriptive psychology, its object, its method and aims. Second, I track the changes and reinterpretations provided by Twardowski in his view of descriptivepsychological analysis. Third, I explore Witwicki's and Bandrowski's-both early students of Twardowski-discussions of the descriptive approach. I try to show that the former accepted psychologism, while the latter overcame it by means of logical analysis. Fourth, I suggest that the only student of Twardowski who renounced the Brentanian method was Ingarden, who developed eidetic phenomenology. Finally, I present Blaustein's - one of the last students of Twardowski - reappraisal of descriptive psychology and his critique of Ingarden's method. This controversy over the method of descriptive psychology reveals how one can situate Twardowski's legacy within early phenomenology in Poland.
\end{abstract}

Keywords Descriptive psychology · Inductive method - Eidetic intuition · Part-whole theory $\cdot$ Brentano $\cdot$ Twardowski $\cdot$ Ingarden $\cdot$ Blaustein

Witold Płotka

witoldplotka@gmail.com; w.plotka@uksw.edu.pl

1 Institute of Philosophy, Cardinal Stefan Wyszynski University in Warsaw, Wóycickiego 1/3, building no. 23, PL-01-938 Warsaw, Poland 


\section{Introduction}

The main aim of this article is to explore the heritage of Franz Brentano's (1838-1917) project of descriptive psychology in Kazimierz Twardowski's (1866-1938) philosophical work and in his students, including Władysław Witwicki (1878-1948), Bronisław Bandrowski (1879-1914), Roman Ingarden (1893-1970) and Leopold Blaustein (1905-1942 [or 1944]). However, given recent publications on the Brentanian legacy in logic, methodology and metaphysics of the Lvov-Warsaw School (e.g., Albertazzi 1993; Poli 1996; Chrudzimski and Łukasiewicz 2006; Jadacki 2009, pp. 61-63; Łukasiewicz 2009; Betti 2017a; Woleński 2017), ${ }^{1}$ in this study, I want to examine how Brentanian descriptive psychology was undertaken and critically elaborated by the school of Twardowski in confrontation with phenomenology. Accordingly, whereas Witwicki and Bandrowski can be labeled rather as psychologists who engaged with Husserl, both Ingarden and Blaustein - on Twardowski's recommendations (Płotka 2017, pp. 81-82) — studied under Husserl and later they formulated original expositions and critiques of phenomenology. At the beginning, it is worth noting that it sounds like a truism to claim that Brentano - the rediscoverer of intentionality and the founder of the idea of philosophy as science - strongly influenced the late nineteenth century and early twentieth century philosophy. The group of his students includes, e.g., Edmund Husserl (1859-1938), Anton Marty (1847-1914), Alexius Meinong (1853-1920), Carl Stumpf (1848-1936) and Twardowski, whose immense contributions to philosophy of that time are beyond any doubt (e.g., Smith 1994, p. 19). Even more, Brentano's ideas have a direct and indirect impact on contemporary research (Zahavi 2004; Kriegel 2018). Given Brentano's all-pervasive presence in philosophy, this article is an attempt to track and define Brentano's legacy and to especially elaborate on the idea of descriptive psychology in early phenomenology. As it is well known, Husserl (1987, p. 304) studied under Brentano between 1884 and 1886. Yet, Brentano's vast importance for the rise and development of Husserl's thought has been extensively examined (De Boer 1978; Rollinger 1999; Fisette 2018). Accordingly, I here seek to deepen the current research on Brentano, by asking about his influences on Twardowski and his phenomenologically-oriented students. Before doing so, I should address the question: What sense does it make, however, to invoke Twardowski and his students in this context?

Twardowski, who studied in Vienna from 1885 to 1889 , had an occasion to hear Brentano's lectures on descriptive psychology in the winter semesters in $1887 / 88$, and in 1888/89 (Dąmbska 1978; Brożek 2011, pp. 118-154). In the "Self-Portrait," which was originally written in 1926, Twardowski $(1991,1999)$ expressed an intellectual debt to Brentano, especially to his method. Nonetheless, throughout his academic career in Lvov he repeatedly redefined psychology, its object and its methodological scope. While he initially did occupy the position of psychologism, after the lecture of Husserl's Logical Investigations, he rejected it as leading to skepticism. His students elaborated the idea of descriptive psychology by juxtaposing it—despite Twardowski's

\footnotetext{
${ }^{1}$ As Jadczak (1995, p. 16) puts it, "[a]nalytical philosophy as developed by members of the Lvov-Warsaw School has its sources mainly in the fought of Brentano."
} 
criticism of phenomenology as such-with Husserl's philosophy and his method. This led them (except for Ingarden) to a revaluation of descriptive psychology. All in all, their struggles to define phenomenology in confrontation with descriptive psychology mirror - to some extent-Husserl's own attempts to explain what phenomenology is and to show its novelty. After all, in the first edition of his Logical Investigations, Husserl understood phenomenology primarily as descriptive psychology (Husserl 1984a, p. 24, footnote; Fisette 2018), but later redefined it as eidetic and transcendental philosophy. Thus, by exploring the line of Brentano-Twardowski-Twardowski's students and by raising the question of the descriptive-psychological method in this article, I will shed new light on how to understand phenomenology as such. In addition, the question of Brentano's and Twardowski's influences on early phenomenology in Poland still needs to be explored. The question becomes even more important when one realizes the mutual philosophical influences of Husserl on Twardowski and viceversa (Schuhmann 1993; Cavallin 1997; Rosiak 1998; Rollinger 1999, pp. 139-153). In sum, the aim of the article is twofold: historical and more systematic. First, I situate Brentano's project of descriptive psychology within the context of disputes in the school of Twardowski concerning the method of both psychology and phenomenology. I argue that descriptive-psychological analysis was dominant in this respect. Of course, given that all of the mentioned philosophers presented sophisticated theories, I could not and do not offer an exhaustive analysis of their positions. Rather, while executing the first aim, I offer an overview of the main positions regarding Brentano in the LvovWarsaw School. Second, the study explores the notion of phenomenology, especially eidetic phenomenology, as founded on a methodological procedure, which presumed the capacity to guarantee infallible descriptions.

To begin with, first, the article sketches the main points of Brentano's idea of descriptive psychology. I focus on the methodological grounds of Brentano's project. So, I define distinctive features of mental phenomena, inductive-deductive tools used to formulate general laws of the psyche and classificatory approach of the project. I also explore an ontological background of Brentano's project, i.e., a mereological view of mental phenomena. Second, I attempt to track changes and reinterpretations provided by Twardowski in his view of descriptive-psychological analysis. With this regard, I show how Twardowski shifts the object of investigation of psychology: instead of mental phenomena, he writes about psychic facts. At the same time, these psychic facts are still understood as mereological objects. I suggest that Twardowski's main contribution to Brentano's project is the new insight that there are four different classes of psychic facts, and he also refutes psychologism. Third, I explore Witwicki and Bandrowski's - both early students of Twardowski-discussions of the descriptive approach and I try to show that whereas the former accepted psychologism, the latter adopted logical analysis and for this reason he overcame it. I aim to show how both students of Twardowski advanced and investigated Husserl's early philosophy. Fourth, I explore Ingarden's critique of Brentano's and Twardowski's projects of psychology. I suggest also that Ingarden is the only student of Twardowski who rejected the Brentanian method in favor of eidetic phenomenology. Finally, I present Blaustein's - one of the last students of Twardowski - reappraisal of descriptive psychology and his critique of phenomenological-eidetic method. My ultimate thesis is that the controversy over the method of descriptive psychology shows how one can situate the Brentanian-Twardowskian legacy within early phenomenology in Poland. 


\section{Brentano's idea of psychology}

Brentano's project of psychology is, of course, complex. Initially Brentano labeled psychology as "empirical," later as "descriptive," or as "psychognosy." The first label comes from the Psychology from an Empirical Standpoint, published in 1874, and it is rooted, first, in the late nineteenth century discussions on the status of psychology, especially on its methodological autonomy (Feest 2014; Seron 2017, p. 36) and, second, in Brentano's early interests in Aristotle and metaphysics - especially the question of immorality of the soul-what resulted in the fact that "the Psychology was to end with a proof or a set of proofs for the thesis that the soul is immortal from the standpoint of some sort of metaphysical dualism, thoroughly justified from an empirical standpoint" (Rollinger 2012, p. 297). ${ }^{2}$ In turn, those two last labels are connected with Brentano's elaboration of his project from 1887 to 91 . At that time he comprehended descriptive psychology as a preliminary discipline for genetic psychology, which - in contrast to the descriptive approach - explores physiological background of psychological processes and is a science based on genetic experiments (as opposed to psychognostic experiments in psychognosy) (Brentano 1982, p. 5; 1995a, p. 7). Of course, both projects, i.e., the 1874 book and the 1887-91 lectures, are different, e.g., whereas the question of genetic psychology is absent in the former, it plays an important role in the latter (cf. Seron 2017, pp. 35-36). At bottom, Brentano's idea of psychology is designed as a research project which explores and classifies types of consciousness. ${ }^{3}$ Brentano defines the object of the project, its method, and aims.

In his early book, Brentano classifies psychology as "empirical," i.e., as a discipline which is interested exclusively in phenomena. In this regard, Seron (2017, p. 35) explains Brentano's early project as a "purely phenomenalistic science" (ausschlisslich phänomenalen Wissenschaft), so, to be precise, as the project that Brentano (1874, p. 17; 1995b, p. 10) ascribes to John Stuart Mill (1806-1873). Psychology, of course, is not interested in all types of phenomena. The object of psychology is famously defined by Brentano (1874, pp. 10, 111; 1995b, pp. 6, 65) as mental phenomena (psychischen Phänomene), which are either presentations (Vorstellungen) or are based upon presentations. In the Psychology, Brentano delineates three distinctive features of mental phenomena. First, they are defined by intentionality, which is understood as the mental inexistence of the object. By "mental inexistence of the object" is meant that every mental phenomenon refers to a content and is directed toward an object (Brentano 1874, p. 115 ; 1995b, p. 68; cf. Chrudzimski 2001). Second, all mental phenomena are only perceived in inner perception or consciousness (Brentano 1874, p. 118; 1995b, p. 70). Inner perception, in turn, is characterized by immediate, i.e., infallible self-evidence. As based on inner consciousness, however, inner perception has a dual object. For Brentano

\footnotetext{
${ }^{2}$ In the Psychology, Brentano writes: "[i]n the case of the investigation concerning immortality the procedure will also be deductive, and the deduction will rest upon factual generalizations which have been inductively established in earlier discussions. This investigation, which touches upon a problem that has always aroused the most vivid interest, will obviously have to assume a new character in many respects. On the one hand, it will be impossible to avoid taking greater account of some metaphysical laws than a phenomenalistic psychology would ordinarily do. On the other hand, it will have to make much more use of the results of physiology than we do in the earlier investigations" (Brentano 1874, p. 95; 1995b, p. 54, emphasis mine). I should like to thank the anonymous reviewer of the journal for bringing to my attention this quote.

${ }^{3}$ For an overview of Brentano's method of descriptive psychology, see Mulligan and Smith 1985.
} 
(1974, p. 118; 1995b, p. 119), namely, every act possesses both consciousness of an object (a primary object of consciousness) and awareness of the act itself (a secondary object of consciousness). But if this is the case, perception of consciousness, i.e., inner perception, is divided into two objects; for this reason, strictly speaking, such an act is impossible since it has its own object, distinct from the present, i.e., introspective experience. Given this, Brentano differentiates between inner perception and inner observation (i.e., introspection). The latter is based on remembering previous experiences (Brentano 1874, pp. 42-43; 1995b, p. 26). In this regard, as Seron explains: "[w] hat the psychologist innerly perceives when she introspects her mental act $A$ is not $A$ but her act of remembering $A$ " (2017, p. 36). Thus, inner observation (i.e., introspection) enables one to "observe" mental phenomena in a non-perceptual mode, namely as remembered phenomena. Again, inner observation is here different from inner perception. Finally, any mental phenomenon is given as a whole, which means for Brentano that consciousness is given as a unity. Accordingly, he draws a sharp distinction between unity and simplicity. The former, namely, is given as a complex whole and thus does not appear as a simple object. Therefore, various acts are, as Brentano puts it, "parts of one single phenomenon in which they are contained, as one single and unified thing" (1874, p. $126 ; 1995 b$, p. 74). In this regard, Brentano specifies that "the parts which can be distinguished in [the phenomenon] are to be regarded as mere divisions of a real unity" (1874, p. 216; 1995b, p. 128). In a word, mental phenomena are conceived as mereological objects, i.e., as wholes which can be decomposed into its parts. ${ }^{4}$ This clarification of phenomena, however, helps to generate the method of psychology.

For Brentano, according to his later project presented in the 1887-91 lectures, psychology is "pure" and "descriptive." The former refers to the fact that a psychologist is not interested in the causes of mental states (Brentano 1982, p. 2; 1995a, p. 4), but rather in its structure. The latter is connected with the requirement that psychology provides us with different types of consciousness and that psychology enables to identify those types via description. In other words, psychology descriptively analyses mental phenomena. This characteristic corresponds with a mereological structure of mental life. Generally speaking, Brentano (1982, pp. 12-13; 1995a, p. 15) differentiates between actually separable parts and merely distinctional parts, i.e., elements of a whole that cannot be separated from other elements of the whole. Due to purely conceptual means, description enables one to identify not only separable parts, but first and foremost distinctional parts. Psychology is descriptive in the sense of providing description of the unity of mental life as composed of separable parts and elements. Yet, to do this, one has to use a five-steps procedure presented in the lectures of 1890-91: "(a) [h] has to experience [erleben], (b) he has to notice [bemerken], (c) he has to fix [fixieren] what he notices, in order to collect it, (d) he has to generalize inductively; (e) where the necessity or impossibility of a unification of certain elements becomes clear from the concepts themselves, he must intuitively grasp these general laws; (f) finally, we can add that he has to make deductive use of what he gained, in one way or another, from general laws" (Brentano 1982, p. 28; 1995a, pp. 31-32). To describe mental phenomena, first, one has to experience something and subsequently, he or she has to determine what he or she experiences by naming and defining it. Later one uses

\footnotetext{
${ }^{4}$ On Brentano's use of mereology in his project of psychology, see Brentano 1982, pp. 79-83; 1995a, pp. 8387. See also Libardi 1996, pp. 38-40, Dewalque 2013 and Curvello 2016.
} 
indictive and deductive methodological tools, however, always in the limits of intuition, as Brentano observes already in the Psychology from an Empirical Standpoint (Brentano 1874, p. 98; 1995b, p. 53). What is important is that Brentano (1874, pp. 94-95; 1995b, p. 54) emphasizes a value of the inverse deductive method which is called by Mill (1843, pp. 585-612) the historical method. This method consists in a formulation of laws by induction and then in their generalizations.

The aim of Brentano's project of psychology is to "provide us with a general conception of the entire realm of human consciousness" (Brentano 1982, p. 2; $1995 \mathrm{a}$, p. 4). This general aim requires description and determination of the components or elements of consciousness. At the same time, this description and determination should be, at least as a methodological postulate, exhaustive (Brentano 1982, p. 79; 1995a, p. 83). Already in Psychology, the description leads toward a classification of mental phenomena, which results in the threepartial distinctions between presentations (Vorstellungen), judgments (Urtheile) and acts of love and hate (emotions) (Gemüthsbewegungen) (Brentano 1874, p. $346 ; 1995$ b, p. 206). This counter-intuitive division is supported by Brentano with complex arguments which aim to show that, first, to judge it is not necessary to have presentations at the same time, and that acts of will and feelings are necessarily connected. In any case, the ultimate aim of Brentano's project of psychology is to formulate the laws that govern each class of mental phenomena. This last aim was formulated by Brentano as a methodological postulate and he was aware that the 1874 book presented only a selection of such laws.

Brentano's project of psychology-regardless of detailed differences between the 1874 book and the 1887-91 lectures, e.g., the above mentioned status of genetic psychology - can be summarized as follows: (1) the object of psychological study are mental phenomena; (2) they are accessible in inner perception, which is infallible and self-evident; (3) all mental phenomena are mereological objects, i.e., wholes composed from separable parts and elements; (4) the method of psychology consists in a descriptive analysis of psychic phenomena; (5) the method adopts inductivedeductive tools to formulate general laws that govern mental phenomena, and finally, (6) the aim of psychology is to classify mental phenomena.

\section{Twardowski between psychologism and anti-psychologism}

In her recent study, Betti (2017b, pp. 306-307) lists four theses that Twardowski shared with Brentano: (1) descriptive psychology is the fundamental science; (2) descriptive analysis is the method of descriptive psychology; (3) descriptive psychology is primary with respect to genetic or experimental psychology; and (4) ethics has cognitive content based on emotional experience. Betti's general claim is that Twardowski undertook the main motives, concepts, methods and arguments of Brentano's psychology in his early phase-presented mostly in the "Psychology vs. physiology and philosophy" article (Twardowski 1965, pp. 92-113; 1999, pp. 41-64), originally published in Polish in 1897-when he was an adherent of a methodological psychologism. Betti (2017b, p. 306), however, notices that Twardowski changed his 
position. In this part of the article, I investigate Betti's (1)-(3) theses and thereby explore in more detail to what extent Twardowski continued Brentano's project of psychology and how he redefined it. More precisely, I discuss Twardowski's approach to the object, method and aims of psychology.

For Twardowski (1965, pp. 206, 242-243), the general object of psychological investigations is psychic life understood in a twofold sense. Twardowski understands the psychic life either as psychic functions (or processes) or as psychic products, which arise as results of such functions. Initially, e.g., in his 1897 text, Twardowski (1965, p. 94; 1999, p. 43) employs the Brentanian language of "psychic phenomena." Later, however, e.g., in the texts on psychology from 1910 and 1913, while defining the object of psychology he instead uses phrases like "psychic facts" and "psychic dispositions" (Twardowski 1965, pp. 206, 244). Twardowski defines psychic facts as non-spatial objects, which are experienced directly in inner experience. In turn, natural objects are spatial and experienced through the outer senses. Despite the terminological differences, following Brentano, Twardowski (1965, p. 244) still comprehends psychic life as a mereological object, i.e., as a unity of functions and products, called also a concrete whole, which is decomposed - by way of abstraction ${ }^{5}$ - into separable parts and elements. ${ }^{6}$

The structure of the object also determines the method of psychology, which consists in a descriptive analysis of the wholes of psychic facts that enables one to identify the simplest elements of psychic life (Twardowski 1965, p. 250). For this reason, in the 1913 text on psychology, which was prepared as an encyclopedic entry, Twardowski (1965, p. 255) explicitly postulates to use the labels "descriptive" and "analytical" interchangeably in the context of psychology. The basis for the analysis is experience; more precisely, it is inner experience or introspection. In a Brentanian fashion (cf. Brentano 1874, pp. 39-40; 1995b, p. 24), Twardowski claims that Comte's refutation of both inner perception and observation is unjustified, because they are not identical (1965, p. 96; 1999, p. 46). While the former, consists in simple experience of the object and thus it is infallible, ${ }^{7}$ the latter is based on a complex act that binds original experience with an additional act of attention. Because of the complexity, observation fails in comprehending the original experience and it is thus fallible. ${ }^{8}$ More exactly, inner observation fails in the actual perceiving the object, which - in turn-is accessible in inner perception, i.e., introspection. Comte was right, then, in excluding observation of psychic phenomena as the method of psychology, but he failed in defining the value of inner perception (Twardowski 1965, pp.

\footnotetext{
5 In Twardowski's psychology "decomposition" cannot be understood as an abstraction in a strict sense. Rather, it refers to the procedure of descriptive identification of the parts - both separable and inseparable — of psychic life. The parts are, then, "abstracted" (in a broad sense) form the whole of psychic life. I am thankful to the anonymous reviewer of the journal for this suggestion.

${ }^{6}$ On Twardowski's mereology and a comparison with Husserl's whole-parts theory, see Rosiak 1998.

${ }^{7}$ Introspection is infallible, according to Twardowski (1965, p. 257), since it guarantees the existence of its object. As he claims, it is impossible that there is no object which is introspectively and actually given.

${ }^{8}$ In the 1910 text on the method of psychology, Twardowski (1965, p. 209) emphasizes that a psychologist cannot be divided into two persons from whom the first person would experience something, whereas the second can track and observe the experience. By "observation" Twardowski understands systematically organized perceptions which serves one to be aware of next phases of a certain phenomenon and its features.
} 
98-99; 1999, p. 48). Because any observation of psychic phenomena is impossible (as a perceptual experience), what remains is inner perception, i.e., introspection. Nonetheless, Twardowski (1965, p. 99; 1999, p. 49) notices a flaw in introspection; namely, it limits infallible and evident cognition to mere subjective life. In other words, a psychologist can introspect only her own psychic life (cf. Rzepa and Stachowski 1993, p. 237). For this reason, Twardowski, following Brentano, ${ }^{9}$ accepts memory as the source for psychological knowledge and consequently, he accepts (to some extent) inner observation which, just as for his teacher, is based on memory. In addition, Twardowski (1965, p. 210) explicitly accepts-just as Brentano did while referring to Mill-the inverse deductive or historical method in psychology, which consists in reconstructing someone's psychic life on the basis of given psychic products and by presupposing general psychological laws.

So far, Twardowski follows Brentano's idea of the method of psychology. Nonetheless, there are at least two important disagreements here. First, Twardowski (e.g., 1965, pp. 100-101, 214, 262-263; 1999, pp. 50-51) accepts psychological-experimental methods as a necessary supplementation of descriptive analysis. As van der Shaar puts it, "Twardowski does not agree with Brentano that there is a strict distinction between empirical and experimental psychology, or between descriptive and genetic psychology, as Brentano calls it. The method of inner perception needs to be supplemented by results of, for example, Wundt's experiments, which have the advantage of being repeatable and being accessible not only to the agent who has the perceptions" (Van der Schaar 2015, pp. 21-22). For Twardowski, the experimental method of psychology (in Wundt's sense) is the objective method in contrast to the subjective method of introspection. Psychology can only become a true science, then, when the experimental methods are employed. Second and more importantly, Twardowski-contra Brentanoultimately takes an anti-psychologistic position. Even though in the 1897 text, Twardowski clearly declares that psychology is the fundamental science (1965, p. 107; 1999, pp. 57-58) - and by doing so, he adopts the position of a methodological psychologism — as early as 1903, he refused psychologism in logic. ${ }^{10}$ Twardowski's decisive step toward anti-psychologism, however, was formulated later (1965, pp. 217240; 1999, pp. 103-132) in the 1911 text on "Actions and Products," wherein he draws a clear distinction between psychic processes and products. Although some scholars (e.g., Paczkowska-Łagowska 1980, pp. 55-79; Czerny 1987, pp. 79-80; Kleszcz 2006)—

\footnotetext{
${ }^{9}$ As Brentano (1874, pp. 42-43; 1995b, p. 26) notices, "[i]n truth, psychology would become impossible if there were no way to make up for this deficiency. We can make up for it, however, at least to a certain extent, through the observation of earlier mental states in memory. It has often been claimed that this is the best means of attaining knowledge of mental facts, and philosophers of entirely different orientations are in agreement on this point."

${ }^{10}$ Methodological psychologism maintains that psychology is the theoretical discipline which underlies other disciplines. A consequence of this form of psychologism seems to be the ontological one: the object of any discipline is regarded as, or reduced to mental phenomenon. E.g., psychologism in logic reduces the ideal and objective meaning-content to psychological content. This, however, leads toward skepticism since psychological entities are accidental. As Twardowski writes, "[o]ne has to defend logic against psychologism since on this way it is easy to get to skepticism" (Twardowski 1903, p. 113). It seems that although methodological psychologism can be developed despite its ontological consequences (as Husserl [1984a, p. 24, footnote] attempted to do in the first edition of his Logical Investigations while defining phenomenology as descriptive psychology), for Twardowski both tendencies are inseparable. I am thankful to the anonymous reviewer of the journal for this suggestion.
} 
pace Ingarden (1938, p. 28) — question whether the 1911 text marks Twardowski's clear break with psychologism, it is evident that Twardowski's conclusion, that there is a sharp distinction between the psychic process and its objects, already overcomes psychologism and - to some extent - it mirrors Twardowski's $(1894 ; 1977)$ early analysis of presentations. After all, it can be argued that Twardowski's object-content distinction questions ontological psychologism since it comprehends the object as different from content of presentations. So, Twardowski's refutation of psychologism in logic is based on the differentiation between the thought (object) and the thinking (content). As such it can be tracked in his early Vienna lectures on logic (cf. Twardowski 2016; Betti and van der Shaar 2004). Nonetheless, some scholars (e.g., Chrudzimski 2001, pp. 33-37; Betti 2013) rightly claim that Brentano elaborated the content-object distinction before Twardowski published his Habilitationsschrift in 1894. In any case, Twardowski's anti-psychologism concerns both methodological and ontological issues.

A general aim of psychology, according to Twardowski (1965, p. 250), is to organize diversity of psychic facts and to formulate laws that govern these facts. To formulate the law means, in turn, to explain the psychic fact (Twardowski 1965, p. 253). Next, to organize the sphere of psychic facts means to analyze and to classify both psychic functions and products. What is important is that this classification does not have to refer to practical norms, but instead to essential similarities. Twardowski's approach concerning the goals of psychology, then, appears to mirror Brentano's. In this context, Albertazzi suggests that "Twardowski took from Brentano the triple division of psychic phenomena - that is, the three ways in which we can refer to an object" (1993, p. 14). As presented above, Brentano divides psychic phenomena into presentations, judgments and emotions. Moreover, Brentano binds emotions with will in the third group of psychic phenomena. Albertazzi's claim gives an impression that Twardowski's classification is the same as Brentano's. However, contra Albertazzi, in the 1903/04 lectures on "The psychology of desires and will," Twardowski questions Brentano's arguments to bind emotions with will: Twardowski there states that Brentano's arguments are not convincing (Twardowski 1992, pp. 222-223). Twardowski claims that desires have an intentional structure; moreover, they have to be comprehended as having a whole-part structure in which emotions are proper parts of desires. Emotions, then, are parts of desires, but they cannot be reduced to desires. For this reason, it is justified — as Twardowski concludes - to differentiate emotions from will.

To conclude, we see that Betti's (1)-(3) theses are generally true, however, a closer analysis of Twardowski's position enables one to identify differences between Brentano and Twardowski's philosophies. In sum, (1) Twardowski defines the object of psychology as psychic facts; (2) psychic facts are mereological objects understood as wholes that include their parts; (3) psychology is developed as a descriptive analysis of psychic wholes to determine simplest parts; (4) psychic facts are given in introspection, which is infallible and evident; yet (5) introspection is limited to subjective experience, and for this reason (6) it has to be supplemented by experimental methods; (7) the aim of psychology is to classify psychic facts by a reference to (8) inductive-deductive methods; however, (9) the classification differs from the Brentanian one; finally, (10) initially psychology was regarded by Twardowski as the fundamental science (what resulted in his methodological psychologism), but later he adopted anti-psychologism. 


\section{Witwicki's and Bandrowski's approaches to phenomenology}

Twardowski moved from Vienna to Lvov in 1895. There, he educated a group of philosophers, logicians, psychologists and specialists in humanities, which gave rise to the Lvov-Warsaw School (Woleński 1989). In this section of the article, I will focus on two psychologically-oriented early students of Twardowski, i.e., Witwicki and Bandrowski, who adopted and developed a Brentanian-style of psychology. From this Brentanian point of view, they analyzed some aspects of Husserl's theory of content and his understanding of the phenomenon of thinking. In this section, I define the reasons why Witwicki and Bandrowski did not accept Husserl's method, but rather favored descriptive-psychological and logical analysis respectively.

Witwicki studies philosophy in Lvov in 1896-1901. Though he also studies psychology (in 1901/02) in Vienna under Höfler and in Leipzig under Wundt, he is disappointed with the experimental method of psychology. He prefers how descriptive psychology discloses conscious experience, such that he stays under influences of both Brentano and Twardowski. ${ }^{11}$ Witwicki's (1900) doctorate is the first Brentanian-style doctorate written under Twardowski (Miskiewicz 2003, p. 84). ${ }^{12}$ Witwicki continues the Brentanian line of thought in his habilitation, which is published in 1904, and he is primarily interested in the phenomenon of the will. The problem formulated by Witwicki in this work is expressed in the Brentanian language. Witwicki asks whether the phenomenon of willing is a simple phenomenon, or if, in contrast, it is possible to distil the single complex mental phenomenon of willing into simple parts, which are connected by representations, emotions and beliefs (1904, p. 6). He accepts Brentano's view that willing is connected with actions and he agrees with Brentano's idea that willing contains a belief. At the same time, Witwicki claims that Brentano's position requires further investigation (1904, p. 92). Witwicki develops a descriptivepsychological analysis of willing by classifying different types of desires. While it is in general true-following Rzepa (1991, p. 41) - that Witwicki took over the Brentanian project of descriptive psychology, it is also the case that Witwicki modified Brentano's theory. How than should one define Witwicki's view of descriptive psychology?

Witwicki (1912, p. 4) follows both Brentano and Twardowski by defining the object of psychological study as "mental phenomena," or "psychic facts." He claims that mental phenomena are (1) non-spatial, (2) either presentations or based upon presentations, (3) given in inner experience, (4) given as a unity, and finally, (5) he asserts that every mental phenomenon contains an act, its object and its content. Witwicki questions (1) and (2) by claiming that one can localize his or her mental phenomenon, e.g., by talking about leg pain, and that the thesis no. (2) is too broad since also numbers are presentations (1912, p. 5). While Witwicki accepts (3) and (4), he still limits the method of introspection (Witwicki 1912, pp. 6-7; Rzepa 2002, p. 43). He does so because the method of introspection leads toward subjectivism and because introspection is not

\footnotetext{
${ }^{11}$ On influences of Brentano and Twardowski on Witwicki's psychology see Rzepa 1991, pp. 36-56 and Jadczak 1997, pp. 29-39.

${ }^{12}$ The work concerned abortion as a psychic phenomenon which was understood as a disposition to certain feelings based upon beliefs (Witwicki 1900, p. 40). Witwicki comprehends ambition as a complex act that is founded on both feelings and judgements. He describes different types of ambition, he characterizes them and describes the object of ambition.
} 
evident. By contrast, he appreciates memory as the source for psychological knowledge and he claims that the observation of mental phenomena is a justified psychological method and as such, it is even more valuable than introspection. This claim of Witwicki, however, differs from Twardowski's position, for whom observation was a supplementary method in relation to introspection. Witwicki labels the method of observation, "psychological observation." This method, which is close to the method of natural sciences, consists in systematic research on the mental life of a psychologist and of others' mental lives (Witwicki 1925, p. 29). ${ }^{13}$ Since mental phenomena are complex, ${ }^{14}$ the aim of psychology is to define simple parts of mental life. This is possible due to description, because description consists in an enumeration of parts (Witwicki 1925, p. 27). The general aim of psychology is to analyze, explore and classify types of mental life and to explain them (Witwicki 1925, p. 28). In this context, Witwicki favors Twardowski's four-class taxonomy over Brentano's solution of threeclass taxonomy (1925, pp. 71-72). Witwicki attaches thesis no. (5)-which comes from Twardowski-and he claims that the thesis assumes that objects of mental phenomena are objects for psychological inquiry (1912, p. 10). Consequently, a further aim of psychology is to analyze and to interpret psychic products (Rzepa and Stachowski 1993, p. 240); all psychic products are connected with inner experience respectively (Rzepa 1991, pp. 93-95).

On January 28, 1929 Witwicki (1931) gave a talk at the meeting of the Polish Philosophical Society on the content and object of presentations, in which he referred to Husserl. According to Witwicki, content is a psychic correlate of the object and it serves to represent the object (1931, p. 395). For Husserl, this means that content is directed toward the object. Witwicki claims that the object is identical with its content only if someone incorrectly recognizes the object (1931, p. 403). However, it is possible to comprehend content as the object, e.g., in the case of experience of a color surface after closing her eyes, or if one attempts to present an abstract object, say as a mathematical entity. In those cases, one interprets content (an abstract part of experience) as the object (a concrete entity). Witwicki was aware that, for Husserl, content is different from the object and the only function of content is to represent the object (1931, p. 406). Husserl (1984b, pp. 621-624) arrives at this conclusion because he does not differentiate between - in a phenomenological sense - between grasping content in intuition and grasping content in a mere signitive act. Here, the crucial disagreement with Husserl arises. Whereas, for Husserl, content is an abstract part of experience

\footnotetext{
${ }^{13}$ More on Witwicki's method, see Rzepa 2002, pp. 55-71.

14 The thesis that mental phenomena are complex follows from Brentano, for whom: "[e]very mental act is conscious; it includes within it a consciousness of itself. Therefore, every mental act, no matter how simple, has a double object, a primary and a secondary object. The simplest act, for example the act of hearing, has as its primary object the sound, and for its secondary object, itself, the mental phenomenon in which the sound is heard. Consciousness of this secondary object is threefold: it involves a presentation of it, a cognition of it and a feeling toward it. Consequently, every mental act, even the simplest has four different aspects under which it may be considered. It may be considered as a presentation of its primary object, as when the act in which we perceive a sound is considered as an act of hearing; however, it may also be considered as a presentation of itself, as a cognition of itself, and as a feeling toward itself. In addition, in these four respects combined, it is the object of its self-presentation, of its self-cognition, and (so to speak) of its self-feeling. Thus, without any further complication and multiplication of entities, not only is the self-presentation presented, the selfcognition is known as well as presented, and the self-feeling is felt as well as known and presented" (Brentano 1874 , pp. 202-203; 1995b, p. 119). Therefore, "wherever there is mental activity there is a certain multiplicity and complexity" (Brentano 1874, p. 204; 1995b, p. 120).
} 
given only due to descriptive analysis, for Witwicki, content is a psychic entity, which can be comprehended as a separable object. As a result, Witwicki can be understood as an adherent of psychologism, because he reduces the abstract object to psychic life. This disagreement, as it seems, follows from a methodological background: Witwicki claims after all that both psychic processes and objects are investigated by psychology. Different approach to psychology and phenomenology was formulated by Bandrowski.

Bandrowski-just as Witwicki-belongs to the group of the first students of Twardowski. ${ }^{15}$ In 1905 he completes his doctoral dissertation, which investigates the method of induction (Bandrowski 2015, pp. 29-63). He subsequently studies psychology in London and Göttingen under Müller in 1905/06. As Głombik (1999a, p. 136) notices, it is hard to say whether Bandrowski participates in Husserl's lectures while studying in Göttingen, but the fact remains that after 1906, he refers to Husserl much more frequently (Głombik 1999b, pp. 159-167; 2011). In an article published in 1907, Bandrowski (2015, pp. 125-137) develops a psychologistic analysis of the phenomenon of thinking and - in this context-he refers to Husserl's (1984a, pp. 67-69) analysis from the Logical Investigations on thinking (meaning) and intuition (phantasy). On this occasion, he makes some notes on how to understand descriptive psychology.

So, for Bandrowski (2015, p. 126), the object of psychology is a "psychic phenomenon." He agrees with Brentano that psychology begins with inner experience, but pace Brentano, he claims that an observation of psychic life is possible as a perceptual experience. Yet, psychic life is rather vague and undefined in its quality. For this precise reason, Bandrowski concludes that observation must be supplemented by hypotheses. Even more, Bandrowski (2015, p. 129) disagrees that psychology can be developed on a purely descriptive level; according to him, descriptive psychology has to accept experiments (in Wundt's sense) as a reliable source of knowledge. Accordingly, inner perception has to be verified by experiments. A general purpose of psychology is to define main classes of mental phenomena (Bandrowski 2015, p. 128). Bandrowski $(2015$, p. 125) claims that classifications can be made via reference either to quality of acts or to their intentional character. He explains that if classification adopts quality as a criterion, it differentiates all types of psychic phenomena that can be classified into one group regardless their eventual intentional structure. The first classification includes both intentional and non-intentional phenomena. In turn, if the classification adopts intentional character as a criterion, it includes only intentional phenomena, e.g., beliefs or resolutions. The method of psychology is to analyze complex mental phenomena as sets of simple elements. Consequently, a psychologist first has to "reduce the entire complexity of mental life to elements as simple as possible" (Bandrowski 2015, p. 132). Second, the psychologist has to define psychic phenomena in their quality as clearly and as distinctly as possible. Psychic phenomena are given in a united psychic life, which is understood as a stream of consciousness. As a result of his analysis, Bandrowski differentiates-following Twardowski and Husserl-between intuitions which have a clear quality and thoughts which lack a clear quality, but which have a distinct intention. At bottom, he differentiates nonintentional experiences from the intentional ones.

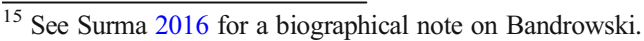


It is worth noting that Bandrowski $(2015, \mathrm{p} .126)$ clearly declares that he adopts an anti-psychologistic position. It seems that this modification of Twardowski's early approach to psychology was made under the influence of Husserl. Nonetheless, Głombik (1999a, p. 130; 1999b, p. 160; 2011) argues that Bandrowski initially occupies a psychologistic position, because he understands logical operations as reducible to psychic processes. To justify this, Głombik first refers to Bandrowski's review_published originally in 1905 — of Nuckowski's handbook of general logic, wherein Bandrowski (2015, p. 106) suggests that psychologistic logic does not have an alternative. Second, Głombik mentions Łukasiwicz's ${ }^{16}$ evaluation of Bandrowski's view on induction as an example of psychologism in logic; indeed Łukasiewicz (1906, p. 175) labels Bandrowski as a psychologist. He does so, because-as Łukasiewicz (1906, p. 138) argues-Bandrowski concludes that there is a causal relationship between the reason and the result, yet understood as mental states; he observes, then, that there is in fact a relation between two mental states (which leads toward psychologism), rather than of two propositions (which leads toward antipsychologism). Surma (2016) disagrees with Głombik and he tries to show that Bandrowski does not adopt a methodological psychologism. According to Surma, Brandrowski favors logical analysis over psychologistic investigations. To prove this point, Surma quotes a fragment of Bandrowski's (2015, pp. 51-52) doctorate in which he comments on Christoph Sigwart ${ }^{17}(1830-1904)$ and states that logical analysis comes before the psychological examinations. If this is the case, as I take it to be, Bandrowski could not have adopted the phenomenological method since for him -in contrast to Husserl - the analysis of language precedes an analysis of the phenomena. Moreover, Bandrowski prefers inductive methods over the eidetic methodology.

In sum, Witwicki and Bandrowski are the first students of Twardowski who put together descriptive psychology with phenomenology. This was possible not only because Husserl's Investigations was a popular book during Twardowski's seminars (cf. Głombik 1999c), but also because of Bandrowski’s studies in Göttingen. Nonetheless, these two thinkers did not adopt the method of phenomenology. The reason why they did not do so, is (1) that Witwicki adopts psychologism, which questions Husserl's eidetics. In turn, (2) Bandrowski favors linguistic analysis over phenomenology, and moreover (3) he values inductive methods. Of course, they both still stay under the influences of Twardowski. (4) Witwicki adopts Twardowki's classification of mental phenomena, and (5) he modifies descriptive psychology-under influences of Twardowski-as focused on psychic products (Rzepa 1991, pp. 55-56, 90-96; Rzepa and Stachowski 1993, p. 240), rather than on psychic acts (processes). (6) Bandrowski refers to Twardowski's differentiation between thinking (meaning) and intuition (phantasy) to develop Husserl's phenomenology of thinking. However, (7) Witwicki-pace Twardowski-adopts the method of observation in descriptive psychology, whereas (8) Bandrowski is skeptical about the method of psychologistic observation and about descriptive psychology in general. Instead, he emphasizes

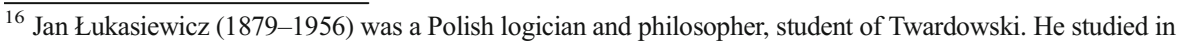
Lvov from 1897 to 1902. In 1902 he gained a doctoral degree on the basis of the dissertation on induction as inverted deduction. On Łukasiewicz and his role in early phenomenology in Poland, see Płotka 2017, p. 8283.

${ }^{17}$ On Sigwart's contribution to the discussions in early phenomenology and to Twardowski's theory, see Betti 2013; Varga 2016.
} 
experimental methods. Rzepa (1999, pp. 126-127) claims that Witwicki adopts a phenomenological attitude (understood in a broad sense) in his analyses of psychic life, i.e., as she argues, Witwicki investigates experience from a phenomenological viewpoint. On the basis of the methodological disagreements, which have been outlined in this section of the article, it is clear that one would not be justified in holding Rzepa's thesis in a strict sense, either with regard to Witwicki or concerning Bandrowski.

\section{Ingarden on how to overcome the Brentanian method toward phenomenology}

Ingarden began his studies in philosophy and mathematics in Lvov in 1911/12. On Twardowski's recommendations, he subsequently moved to Göttingen, where he studied under Husserl, Reinach and Scheler in 1912-14 and 1915/16 and later in 1916/17 in Freiburg im Breisgau. ${ }^{18}$ He completed his doctoral dissertation on Bergson in 1918. Ingarden stayed under influences of Husserl, but his reading of Husserl was critical (e.g., Husserl 1994, pp. 183-200). Moreover, Ingarden (1937, pp. 225-226; 1963, p. 197; 1999) emphasized that the Brentanian tradition, especially the idea of philosophy as science, was popular in Poland thanks to Twardowski. But Twardowski's all-pervasive presence in philosophy in Poland in the first decades of the twentieth century made it hard to fully grasp the novelty of phenomenology. For this reason, Ingarden's first texts, which were published in Poland, came to define phenomenology as opposed to Brentano's and Twardowski's descriptive psychology. Nonetheless, in contrast with Witwicki and Bandrowski, Ingarden (1938, p. 17; 1966, p. 25; 1999) was perfectly aware similarities between Twardowski's and Husserl's approaches. Given this, in this part of the article, I characterize Ingarden's main contribution to the debates concerning methodology in the school of Twardowski. For this reason, I focus on Ingarden's early considerations, i.e., before World War II.

Ingarden repeatedly claims that phenomenology arises as a reaction against both experimental and descriptive psychology in general (Ingarden 1919a, pp. 120-124; 1934a, p. 4; 1934b, p. 39), and against psychologism in logic in particular (Ingarden 1919b, p. 316). He claims that Husserl initially - in his Philosophy of Arithmetic and in the first edition of the Logical Investigations - occupies a psychologistic position (Ingarden 1919a, p. 119; 1919b, pp. 316-317). He also knows that in the second edition of the Investigations, Husserl declares that phenomenology is not a psychology of any sort (Ingarden 1915, p. 309; 1993, p. 7). In this context, Ingarden formulates a complex argumentation to show how phenomenology can overcome psychology. Let me more closely explain this line of argumentation, because it reveals the main disagreements between Ingarden and Twardowski, along with his students.

For Ingarden (1934b, pp. 36-37, 40), experimental psychology is unable to formulate a general and exact theory of psychic life. This means that psychology cannot obtain any general laws. Ingarden arrives at this conclusion because he also believes

\footnotetext{
${ }_{18}$ To be precise, Twardowski recommended Ingarden to study psychology under Müller. Indeed, Ingarden studied psychology at the beginning of his stay in Göttingen, but he was dissatisfied with an empirical background of Müller's approach and after few weeks he decided to join Husserl's classes. Cf. Ingarden 1998, p. 409 .
} 
that experimental psychology is an empirical science, which investigates psychic states, structures and types of real psychic subjects (Ingarden 1994, p. 291). Given that the object of study is empirical, however, one has to employ also empirical methods. At the same time, according to Ingarden (1934b, p. 39), psychology lacks any unifying method and it is founded on an unprecise definition of its object. ${ }^{19}$ In a word, a psychologist operates with fallible methods that cannot ensure infallible results. At the same time, paradoxically, psychologists seek the weakness of psychology in its object, i.e., in the subjective life as the source of skeptical subjectivism. To do so, psychologists - obsessed with the idea of psychology as exact science-attempt to eliminate any subjective element by means of their experiments. However, it is evident for Ingarden (1919a, pp. 129-130) that the empirical experiments of psychologists are not only fallible, but also incorrectly give the impression that a human being is a kind of machine, which reacts automatically to any stimulus. Therefore, in contrast to Twardowski and Bandrowski, Ingarden rejects empirical experiments as the methodological ground for psychology and - given the claim to ensure infallible results - he denies that inductive methods are justified.

Given the weakness of experimental psychology, Ingarden nonetheless does not find descriptive psychology to be a promising alternative. On the one hand, in lectures on Brentano's philosophy - originally given in Polish at the Jan Kazimierz University in Lvov in 1936-Ingarden $(1963$, p. 211 ; 1999) expresses his appreciation of the antimetaphysical attitude of descriptive psychology. On the other hand, he disagrees with a definition of its object and method. The objects of descriptive psychology are psychic facts (Ingarden 1915, p. 306; 1993, p. 4) and this means that the psychologist is only able to investigate mere tokens of psychic phenomena. In his review of Witwicki's Psychology, although Ingarden (1934c, p. 61) concludes that Witwicki's book is a valuable handbook, he still emphasizes that descriptive psychology only serves to explore concrete psychic life since it asks about psychic facts (Ingarden 1934c, p. 62). In contrast, according to Ingarden (1915, p. 306; 1993, p. 4; 1994, p. 291), phenomenology asks about the content of essences of pure experiences as such. For this reason, phenomenology enables one to explore the general structures of experience. Phenomenology, in addition, cannot use Twardowski's language of "psychic life," since this suggests that it is interested only in acts of consciousness, instead of intentional objects of consciousness and its essences. So, for Ingarden, phenomenology explores essences, whereas descriptive psychology examines facts. This significant change is what defines phenomenology as having an absolute character, while descriptive psychology only possesses a relative character. What is similar in both methods is that the phenomenologist and the descriptive psychologist employ description as a methodological tool. While the psychologist describes tokens of psychic phenomena, the phenomenologist "captures them in a descriptive manner ... by means of descriptive essence-concepts and expresses them in a priori propositions (Aussagen)" (Ingarden 1915, p. 306; 1993, p. $5){ }^{20}$ For Ingarden, psychic phenomena are not grasped as tokes (as in descriptive

\footnotetext{
${ }^{19}$ It is worth noting that for Ingarden (1934b, p. 39) this sort of psychology presupposes atomistic view of psychic life what seems to be inadequate given a united character of human experience.

${ }^{20}$ Ingarden presents the following definition of "description": "1) it a certain conceptual presentation of features of the described object; 2) it is possible for the describing person to formulate an adequate description only after a clear and distinct cognition of the described object; 3 ) the description serves to know the object by the subject indirectly" (Ingarden 1922, p. 514)
} 
psychology), but rather with regard to the content of the idea of psychic phenomena. Since description is founded on direct experience, a phenomenologist uses the methodological tool of ideation, which enables one to comprehend the content of the idea (Ingarden 1919a, b). In sum, what differentiates descriptive psychology and phenomenology is their objects of study (tokens of psychic phenomena vs. content of the idea), where this importantly results in a difference in their methodological approaches.

As stated above, Brentano (1874, p. 118; 1995b, p. 70) claims that mental phenomena are available only in inner perception. For Ingarden this means, however, that the source of psychology is fallible since perception is fallible. In contrast, his aim is to ensure the absolute character of phenomenological knowledge. To do so, in a review of the second edition of Husserl's Investigations, Ingarden (1915, p. 306; 1993, p. 4) draws a sharp distinction between immanent seeing of essences (immanente Wesenserschauung) and inner perception (innere Wahrnehmung). Whereas the former is directed toward essences and thus it ensures a priori knowledge, the latter refers to really existing experiences. What Ingarden attempts to do here, is to radicalize Brentano's and Twardowski's emphasis on inner experience, but in contrast to both thinkers, he elevates the status of immanent experience, by claiming that it is infallible. Indeed, in 1936 lectures, Ingarden (1963, p. 212; 1999) accuses Brentano of a vague distinction between inner perception and observation. In this context, Ingarden (1963, pp. 214-217; 1999) formulates five charges against Brentano: (1) Brentano is too hasty in his rejection or limitation of the possibility of direct observation of psychic phenomena; (2) he does not explain how it is possible that memory is fallible, but inner perception is infallible; (3) his description of the way how to acquire knowledge of other subject's life - as per analogiam argument-is not sufficient; (4) Brentano does not clarify how to connect a description of the psychic phenomenon experienced by someone with the psychologist's own experience; finally, (5) he does not specify whether one knows about others' individual psychic phenomena or rather the types of their phenomena. For Ingarden, Brentano's inner perception operates in the subjectobject schema, which results in confusion concerning the contents and the object of an act. For this reason, Brentano's theory does not describe experience adequately: it accounts only for the subject, but does not also describe the experiences of contents (Ingarden 1922, p. 533). Given (1) the subject-object schema of Brentano's inner perception, (2) his idea that there are two objects of every presentation and (3) the thesis that each phenomenon is divided into presentation, judgement and emotions, Ingarden (1963, pp. 233-238; 1999) argues that inner perception falls into the regressus in infinitum, because Brentano complicates the structure of experience by generating further levels of experience. To formulate a theory, which does not have these problems, Ingarden (1921, p. 563) conceives a pure theory of knowledge, which is founded on the intuition of experience (Intuition des Durchlebens). ${ }^{21}$ So, for Ingarden, intuition is not just experienced (erlebt), but it is also lived through (durchlebt). This account, according to Ingarden, does not describe consciousness in line with the subject-object schema and it thus does not fall into the regressus in infinitum error. This advantage is possible since intuition is not an act of consciousness, but rather a state which

\footnotetext{
${ }^{21}$ On Ingarden's project of the pure theory of knowledge, its object and thematic scope, see Chrudzimski 1999, pp. 132-136.
} 
accompanies experiences and it is further possible because intuition does not require an additional act of reflection. ${ }^{22}$ Again, intuition — and not perception - makes the analysis of phenomena possible.

To summarize Ingarden's theory, I highlight ten of his observations. (1) Ingarden accuses descriptive psychology of a lack of general and widely accepted laws. For Ingarden, (2) Brentano is focused on mere concrete phenomena. Thus, (3) the weakness of psychology arises from its object, i.e., psychic facts. Next, (4) Ingarden-contra Twardowski and Bandrowski-rejects empirical experiments as justified tools and moreover (5) he-contra Witwicki-rejects the empirical character of the analysis of phenomena. In this context, (6) Ingarden postulates to adopt a phenomenology, which investigates the content of ideas of experiences. (7) As eidetic discipline, phenomenology uses ideation as a methodological tool (8) which, at the same time, stands in contrast to the inductive-deductive methods postulated by Twardowski and his students. (9) What connects phenomenology with descriptive psychology is a descriptive attitude. (10) Ingarden also emphasizes the value of inner experience, though understood as intuition, rather than-pace Brentano-as perception. It seems that Ingarden is the only pupil of Twardowski who explicitly attempts to overcome the Brentanian method toward phenomenology. However, he does not accept reduction and its idealistic consequences. ${ }^{23}$ In turn, he offers to develop phenomenology as descriptiveeidetic analysis.

\section{Blaustein's reappraisal of descriptive psychology}

Blaustein belongs to the group of the last students of Twardowski. He studies at Jan Kazimierz University in Lvov probably in 1923-27 under Twardowski, Ingarden and Ajdukiewicz. ${ }^{24}$ In accordance with Twardowski's advice, Blaustein studies in 1925 in Freiburg im Breisgau under Husserl. His doctorate concerns Husserl's theory of act and contents. Later in 1927/28 he holds a fellowship in Berlin where he meets Stumpf and he studies Gestaltpsychologie under Wertheimer and Köhler. He there becomes dissatisfied with the naturalistic attitude of experimental psychology (cf. Jadczak 1993, p. 23). He prefers instead a descriptive approach and his opinions concerning this approach was primarily influenced by Twardowski's view on and Ingarden's critique of descriptive psychology. ${ }^{25}$ In this section of the article, I examine Blaustein's reappraisal of descriptive psychology and his critique of eidetic phenomenology.

\footnotetext{
${ }^{22}$ For Chrudzimski (1996, pp. 138-139), despite Ingarden's explicit critique of Brentano's self-awareness, Ingarden solution is comparable to Brentano's ideas for three reasons: (1) intuition of experience (just as Brentano's self-awareness) means that it is always possible to reflect on consciousness; (2) Ingarden accepts (following Brentano) that unconscious mental states - or, more precisely, mental states which cannot be experienced - are impossible, yet (3) it is not necessary to be directed toward a certain mental state to be conscious of it.

${ }^{23}$ Cf., e.g., Ingarden 1975. For discussion, see Wallner 1987; Bostar 1994. Arguably, this traditional reading of Husserl's reduction as leading toward metaphysical idealism was formulated mainly by his students from Göttingen, however, it was challenged within the Husserl scholarship. See Zahavi 2017.

${ }^{24}$ Kazimierz Ajdukiewicz (1890-1963) was a Polish philosopher and logician. He studied in Lvov from 1908. In 1912 he completed his doctoral dissertation - written under Twardowski - on Kant's theory of space. In the 1920's and 1930's he lectured in Lvov, later in Warsaw.

${ }^{25}$ For an overview of Blaustein's philosophy, see Miskiewicz 2009; Pokropski 2015.
} 
Blaustein (1938a; 2005, pp. 3-19) uses descriptive-psychological tools primarily to analyze aesthetic experiences, e.g., watching a movie in the cinema (Blaustein 1933; 2005, pp. 92-127) or listening to the radio (Blaustein 1938b, 1939; 2005, pp. 145196). Nonetheless, he also employs these tools in his pedagogy to describe the psychological background of learning and the background of adolescence (Blaustein $1931 \mathrm{a}, 1935 \mathrm{a}, \mathrm{b})$. His concept of descriptive psychology follows mainly from Twardowski's philosophy. Accordingly, Blaustein (1931a, p. 8; 1935a, p. 34) defines the object of descriptive psychology as "psychic life." Moreover, he claims that the main purpose of psychology is to analyze the structure of the act of consciousness and its object. Of course, the latter demand, i.e., a call to include results of psychic life into a psychological description, follows from Twardowski's-Witwicki's emphasis on psychic products. Psychic life is comprehended by Blaustein as a mereological object, i.e., as a whole composed of its separable and inseparable parts. He writes that the purpose of psychology is to produce "a description of a natural psychic whole, i.e., of the experience or of a complex of experiences, which is not grasped due to any abstraction, but rather ... 'originally given"” (Blaustein 1935a, p. 34). To explain what is "originally given," Blaustein refers to two different issues. First, he binds "original givenness" with introspection (and retrospection). For Blaustein (1931c, p. 183), introspectionwhich is generally understood as clear and distinct seeing-is characterized by infallibility. A psychological description concerns, thus, what is introspectively given. In line with this, Blaustein (1931c, pp. 182-183) contrasts description with hypothesizing. Whereas description expresses what is given directly, hypothesis is given indirectly. ${ }^{26}$ Second, Blaustein states that a psychologist identifies - while describing - moments of experience, which initially are only experienced and are not lived through. Already in his doctorate, Blaustein (1928, pp. 67-68, 78) adopts Ingarden's (1921) division between being experienced (erlebt) and lived through (durchlebt). Given this, Blaustein believes that psychology enables one to live through experiences as experiences. By contrast, in everyday life, one experiences something. Although Blaustein is here following Ingarden's insights, he rejects the eidetic method.

In his doctorate, Blaustein (1928, p. 60) formulates a standard interpretation of Husserl's method of reduction as a change of attitude. The aim of reduction is a modification of the general thesis inherent to the natural attitude. Due to the reduction, the thesis becomes a lived experience. The consequence of the reduction is to define the research field for phenomenology as pure consciousness. Moreover, the main question of phenomenology concerns the essence of immanent experiences. Next, Blaustein argues that essences can only be disclosed via eidetic intuition, and not via simple empirical perception. So far, then, he follows Husserl's phenomenology, as it is presented in Ideen $I^{27}$ In contrast, the later Blaustein formulates a critique of Husserl's method. Blaustein (1928-1929, p. 164b) begins by differentiating between two

\footnotetext{
${ }^{26}$ It can be argued that Blaustein's attempts to define psychology in terms of "original givenness," "hypothesizing" and "indirect givenness" come from Stumpf. As mentioned above, Blaustein studied in Berlin under Stumpf in 1927/28. On Stumpf's view of both descriptive psychology and phenomenology, see Fisette 2018. I am thankful to the anonymous reviewer of the journal for this suggestion. In his analysis of psychology, Blaustein refers also to Wilhelm Dilthey's (1833-1911) idea of descriptive psychology and Eduard Spranger's (1882-1963) (a student of Dilthey in Berlin) idea of humanistic psychology.

${ }^{27}$ On contemporary readings of Husserl's theory of reduction, see Rizzoli 2008; Luft 2012; Zahavi 2017, pp. 56-60.
} 
concepts of phenomenology. First, he outlines the narrow sense of phenomenology, according to which phenomenology is understood as a descriptive science of ideal essences of lived experiences of pure consciousness (pure consciousness is available after performing reduction). Second, in its broad sense, phenomenology is a set of disciplines, or a discipline that investigates ideal essences as such (Blaustein 19281929, pp. 166a-166b). In Blaustein's opinion, however, the status of essences (understood as general objects) is questionable. To clarify this dubiousness, Blaustein (19281929, pp. 164b-165a) lays out five charges that concern (1) logical, (2) epistemological, (3) ontological, (4) psychological and (5) methodological issues.

To begin, (1) from a logical point of view, Blaustein states that a correct (in logical terms) definition of essences presupposes the existence of essences, but the question of the existence or non-existence of essences does not concern logic, but rather ontology. Therefore, this definition requires a perspective, which is different from a purely logical perspective. Next, (2) concerning epistemological issues, Blaustein claims that only eidetic intuition (Wesenschau) enables one to comprehend essences. Nonetheless, in his view, eidetic intuition is a kind of schematic representation, ${ }^{28}$ which, even if it adequately represents some features of an object, does not guarantee that this representation is entirely accurate. Moreover, (3) considering ontology, it is unclear and even intuitively unknown how one can define the existence of general objects. According to Blaustein, the meaning of the word "existence" as "self-givenness" can only be understood via perception. Eidetic intuition, in turn, is not a form of perception. However, (4) considering a psychological perspective, there is no doubt that there are intentions that are directed toward general objects. This, as he states (Blaustein 19281929 , p. 165a), requires a closer description as a description of objects correlated with certain psychic acts. At the same time, this description concerns - in a proper sensethe acts themselves. Finally, (5) from a methodological viewpoint, the existence of a general object has a hypothetical status. Nonetheless, it is hard to say whether such a hypothetical status is necessary for an explanation of certain states of affairs. Given all these charges and doubts, Blaustein (1928-1929, p. 165b) concludes that all eidetic ontologies, both formal and material, are empty. For this reason, he observes that it is questionable if phenomenology can be the basis for empirical sciences. In sum, eidetics falls into the petitio principii error, because it is not justified in explaining the status of essences. $^{29}$

\footnotetext{
${ }^{28}$ According to Blaustein's (1930, p. 57) general description, a schematic representation is a quasi-adequate representation, i.e., a representation in which only the few elements of contents are related to the object. A more precise definition states that " $A$ represents ... schematically $B$ for $X$, if $A$ represents naturally (reconstructs in intuition) $B$ for $X, A$ is intuitively given, but $B$ not, so the presenting content of $A$ is not comprehended as an appearance of $B$ " (Blaustein 1931b, p. 107).

${ }^{29}$ Blaustein's reading of eidetic phenomenology is rather one-sided and it does not account for Husserl's nonPlatonic view of essences as presented in his writings on eidetic variation (Husserl 2012). On Husserl's eidetics, see Sowa 2007, 2012. It is worth noting, however, that Blaustein knew Husserl's lectures on phenomenological psychology in which he participated in 1925; in these lectures, Husserl presented a nonPlatonic concept of essences and he introduced a complex procedure (eidetic variation) which enables one to grasp an essence as the invariant of the series of variable examples. Again, Blaustein knew this theory, but in his text he did not refer to this theory. Some scholars (e.g., Kuliniak, Leszczyna and Pandura [2016, p. 114]) suggest that Blaustein discussed in the text rather with Ingarden (mainly with his Essentiale Fragen, originally published in 1925), than with Husserl.
} 
If so, how is phenomenology possible at all? Blaustein offers to develop phenomenology as descriptive psychology. In his opinion, instead of investigating ideal essences, the phenomenologist should examine types of objects, where types is to be understood as the lowest species. If this is the case, "phenomenology is possible only as empirical and descriptive science of types (the lowest species) of lived experiences of pure consciousness, [s]ince no direct investigation into higher species, unless it is held on the way of inductive generalization, is reliable" (Blaustein 1928-1929, p. 165b). Here eidetic intuition is replaced by introspection (and retrospection); however, this means that this phenomenology also lacks any and all value. Phenomenology, on Blaustein's view can thus be replaced by empirical sciences, i.e., descriptive psychology.

In conclusion, it is worth noting that Blaustein's reappraisal of descriptive psychology results in a form of ontological psychologism. In this context, the key concept is Blaustein's "phenomenal world." Blaustein introduces this concept while engaging with Husserl's view of sensations. According to Blaustein, Husserl introduces sensations in lived experiences to show that objects are intended by sensations. In contrast, Blaustein claims that sensations do not belong to lived experiences, but to the world, which he calls, "the phenomenal world." In his doctorate, Blaustein (1928, pp. 74, 76-77) adopts a general thesis that the world is divided into two parts: the phenomenal and the material. The phenomenal world is comprehended as a set of the presenting content. It serves to be-in a given moment in time - a visible side of the material world which, in turn, is a set of material things. The phenomenal word, then, is the world of sense-contents, colors, sounds, smells, etc., which are placed in twodimensional space. One experiences the phenomenal world as complexes of presenting contents which are interpreted by Blaustein as objects of visible things (Sehdinge). Again, visible things are purely subjective and for this reason, they are different from material entities. As Blaustein (1928, p. 76) puts it, "[p]henomenal objects do not exist in the material world, but in the phenomenal world which presents the material world." All in all, sensations are for Blaustein (1928, p. 77) adumbrations of material object's properties and at the same time they are elements of phenomenal objects which represent material objects. Pokropski (2015, p. 97) emphasizes this point by writing, "Blaustein does not elaborate further metaphysical consequences of this claim and restricts his investigations only to the phenomenological and descriptive level". At the same time, it is evident that Blaustein's position does not concern purely phenomenological issues, but also ontological issues. In sum, it is justified to claim that Blaustein adopted psychologism as an ontological thesis by reducing the object given in experience to the complex of subjectivephenomenal experiences.

Blaustein's approach to the method in the school of Twardowski can be summarized as reappraisal of descriptive psychology in favor of Ingarden's eidetic approach. Accordingly, (1) Blaustein - contra Ingarden - accuses phenomenology of falling into the petitio principii error, since it cannot explain the status of essences. Moreover, (2) phenomenology is based on intuition, which is not a form of perception, and for this reason phenomenology cannot justify knowledge. In contrast, (3) descriptive psychology is based on introspection (and retrospection) - understood as inner perception- 
which ensures the infallible character of psychological knowledge. (4) The object of psychology is understood by Blaustein as "psychic life," which (5) is comprehended as a mereological object. (6) The aim of psychology is to describe types of experiences, the structures of experience and (following Twardowski and Witwicki) the results of experiences. Next, (7) Blaustein also adopts ontological psychologism by reducing the object of experience to the phenomenal aspect of experience. In the end, it is worthwhile to note that Blaustein seems to be aware of the methodological problems inherent to the descriptive-psychological approach. After all, if the essences are replaced by types and intuitions are replaced by introspection, those changes give an impression that psychology is empirical science which operates only with inductively certain results. In this regard, (8) Blaustein (1931a, pp. 9-10) notices that experiments and interviews are fallible: they are unable to ensure the infallible character of psychology. (9) Instead, he offers to "anonymize" described experiences, i.e., not to comprehend them as parts of concrete psychic life (Blaustein 1935a, p. 36).

\section{Conclusions}

The Lvov-Warsaw School was, of course, a diverse group of philosophers, logicians, psychologists and, more generally, scholars connected to humanities (Woleński 1989). Given its historical context, it is hard to deny that the Brentanian legacy was an important factor, which shaped a methodological and conceptual framework of the School, mainly with regard to the idea of philosophy as science and the analytical approach (Łukasiewicz 2009; Woleński 2017). This study — which explored the impact of the Brentanian legacy on the Lvov-Warsaw School-raised the question of how Twardowski and his students comprehended the method of descriptive psychology. This general question was rephrased here with regard to the specific question of how they explored the descriptive-psychological approach in the context of phenomenology. Simply stated, the paper examined the line of Brentano-Twardowski-Twardowski's students as an example of a juxtaposition of descriptive psychology with phenomenology. Of course, with this, I do not mean to suggest that the Lvov-Warsaw School was simply a part of the phenomenological movement. To the contrary, that School criticized many aspects of Husserl's philosophy. Instead, I aimed at here to shed new light on Twardowski and his students, namely, to present an overview of how they critiqued and interpreted phenomenology as a discipline.

Generally speaking, I think there are at least four points, which mark breakthroughs within this Brentanian legacy. First of all, the controversy concerned (1) the object of analysis. This resulted in (2) the question of how to provide analysis, i.e., the question of method. Next, (3) the taxonomy of mental phenomena was questionable. Also (4) the issue of psychologism and its possible overcoming was equally important. Despite the differences, however, I suggest that there are also two clear tendencies, which connect Brentano, Twardowski and his students, namely, (5) a descriptive attitude and (6) a mereological background.

(1) The objects were defined as mental phenomena (Brentano), psychic facts (Twardowski, Witwicki, Bandrowski), the content of essences of pure experiences (Ingarden), or types of experiences (Blaustein). In this respect, e.g., Witwicki (1925, p. 40) or Blaustein (1928-1929, p. 165b) suggested that only facts or types can be 
generalized in further investigation, whereas essences are hypostases. In turn, for Ingarden $(1915$, p. 306; 1993, p. 5) only essences can justify infallible knowledge. In sum, this disagreement resulted in (2) a more general issue of methodology, which can be divided into three more specific divergences. First, (a) Twardowski, Witwicki, Bandrowski and Blaustein followed Brentano's emphasis on inductive-deductive tools. In turn, Ingarden preferred the eidetic approach, which consisted in a variation of the real object in order to grasping the ideal object. A more complex divergence concerned (b) the question of the epistemic value of observation. Of course, Twardowski followed Brentano in claiming that observation of psychic life was non-perceptual experience and as such it had limited value. Nonetheless, his students, e.g., Witwicki, Bandrowski and (to some extent) Ingarden held an opposite position. Finally, (c) Twardowski and Bandrowski followed Brentano's demand to include empirical experiments into their analyses, but Witwicki, Ingarden and Blaustein claimed that this is only possible in a limited range (Witwicki, Blaustein), or even counterproductive (Ingarden). Next, (3) Twardowski's four-class taxonomy of psychic facts replaced Brentano's three-class taxonomy. Twardowski's solution was widely accepted by his students (Witwicki, Bandrowski, Blaustein). This marked a sharp distinction between the Lvov-Warsaw School and the Brentanian tradition. The same seems to hold for the thesis no. (4), however, in a limited range. It is true, as Betti (2017a, pp. 338-339) claimed that Twardowski's (and Twardowski's students') main disagreement with Brentano concerned anti-psychologism in logic and formal methods. At the same time, given the question of descriptive psychology, Betti's thesis simply does not hold. As presented above, early Twardowski adopted a methodological psychologism, but later became an adherent of anti-psychologism. I think that Witwicki and Blaustein continued with the former tendency, whereas Bandrowski and Ingarden continued with the latter. In this way, the students of Twardowski were divided. What connected them was (5) a descriptive approach understood in a Brentanian fashion. This factor followed from a common source of the school of Twardowski and phenomenology. Ingarden (1938, p. $17 ; 1966$, p. 25 ; 1999) claimed that - in spite of all differences-Twardowski's approach was comparable to the phenomenological one, which consisted in a careful analysis of experience. This resulted in (6) a common thesis that mereology is the background of analysis, i.e., a descriptive approach was connected with a mereological view of the described object, say, psychic phenomena (Brentano), psychic facts (Twardowski, Witwicki, Bandrowski), or its types (Blaustein) and the content of essences of pure experiences (Ingarden) which all were comprehended as wholes composed of parts.

Finally, given all gaps and convergences, one important lesson that can be drawn from the presented struggles with the Brentanian legacy is that a controversy of descriptive psychology vs. phenomenology is dependent upon ontological and-consequently-methodological assumptions. At bottom, if the objects of study are regarded as real, e.g., as psychic facts, this results in a deductive-inductive approach and further necessitates a reappraisal of empirical-experimental methods. In contrast, if the objects of study are regarded as ideal, then an eidetic approach and a refusal of experimental methods follows. Only Ingarden, as a member of the school of Twardowski, adopted - under influence of Husserl - the latter view. But, for Husserl, a refutation of psychologism inherent to descriptive psychology was possible due to the reduction, which differentiates the descriptive-eidetic approach (from the Logical 
Investigations), on the one hand, from its transcendental reformulation (as introduced in Ideas I), on the other. ${ }^{30}$ Although Ingarden did not accept transcendental methodological tools, I think that his critique of descriptive-psychological approach shows how to overcome problems connected to the Brentanian view of experience.

Acknowledgments The project is financed by the National Science Centre, Poland (no. 2017/27/B/HS1/ 02455). Early versions of parts 3, 5-6 were read at the International Conference on "Brentano-Comte-Mill: The Idea of Philosophy and Psychology as Science," Institute for Philosophy Alexandru Dragomir" in collaboration with the Faculty of Philosophy, University of Bucharest, Romania (September 27-28, 2018) and I thank the participants of that conference for their helpful comments, especially I thank Guillaume Fréchette and Ion Tănăsescu for their stimulating remarks and exchanges. I would like to express my gratitude to the two anonymous reviewers of the journal for their helpful suggestions and inspiring comments. I also would like to thank Thomas Byrne for revising the language of the manuscript.

Open Access This article is distributed under the terms of the Creative Commons Attribution 4.0 International License (http://creativecommons.org/licenses/by/4.0/), which permits unrestricted use, distribution, and reproduction in any medium, provided you give appropriate credit to the original author(s) and the source, provide a link to the Creative Commons license, and indicate if changes were made.

\section{References}

Albertazzi, L. (1993). Brentano, Twardowski, and Polish scientific philosophy. In F. Coniglione, R. Poli, \& J. Woleński (Eds.), Polish scientific philosophy: The Lvov-Warsaw School (pp. 11-40). Amsterdam: Rodopi.

Bandrowski, B. (2015). In P. Surma (Ed.), Logika, analiza mowy, psychologia. Warsaw: Semper.

Betti, A. (2013). We owe it to Sigwart! A new look at the content/object distinction in early phenomenological theories of judgment from Brentano to Twardowski. In M. Textor (Ed.), Judgement and truth in early analytic philosophy and phenomenology (pp. 74-96). New York: Palgrave Macmillan.

Betti, A. (2017a). Brentano and the Lvov-Warsaw School. In U. Kriegel (Ed.), The Routledge handbook of Franz Brentano and the Brentano school (pp. 334-340). New York: Routledge.

Betti, A. (2017b). Twardowski and Brentano. In U. Kriegel (Ed.), The Routledge handbook of Franz Brentano and the Brentano school (pp. 305-311). New York: Routledge.

Betti, A., \& van der Shaar, M. (2004). The road from Vienna to Lvov: Twardowski's theory of judgement between 1894 and 1897. Grazer Philosophische Studien, 67, 1-20. https://doi.org/10.1163/1875673590000821.

Blaustein, L. (1928). Husserlowska nauka o akcie, treści i przedmiocie przedstawienia. Lvov: Nakładem Towarzystwa Naukowego z Zasiłkiem Ministerstwa Wyznań Religijnych i Oświecenia Publicznego.

Blaustein, L. (1928-1929). Próba krytycznej oceny fenomenologii. Ruch Filozoficzny, 11, 164b-166b.

Blaustein, L. (1930). Przedstawienia imaginatywne. Studyum z pogranicza psychologii i estetyki. Lvov: Wydawnictwo Polskiego Towarzystwa Filozoficznego we Lwowie.

Blaustein, L. (1931a). O ocenie samego siebie w wieku młodzieńczym. Poznań: Poznańskie Towarzystwo Psychologiczne.

Blaustein, L. (1931b). Przedstawienia schematyczne i symboliczne. Badania z pogranicza psychologji $i$ estetyki. Lvov: Nakładem Przeglądu Humanistycznego.

Blaustein, L. (1931c). W sprawie wyobrażeń imaginatywnych. Przeglad Filozoficzny, 34(2-3), 180-187.

Blaustein, L. (1933). Przyczynki do psychologii widza kinowego. Poznań: Poznańskie Towarzystwo Psychologiczne. Reprinted in Blaustein, L. (2005). Wybór pism estetycznych (pp. 92-127). Z. Rosińska (Ed.). Krakow: TAiWPN Universitas.

Blaustein, L. (1935a). O zadaniach psychologii humanistycznej. Przeglad Filozoficzny, 38(1-2), 33-57.

Blaustein, L. (1935b). Psychologiczne podstawy oświaty pozaszkolnej. Warsaw: Powszechny Uniwersytet Korespondencyjny.

$\overline{{ }^{30} \text { With this regard, see a classical }}$ reading of de Boer (1978). 
Blaustein, L. (1938a). O ujmowaniu przedmiotów estetycznych. Lvov: Lwowska Bibioleta Pedagogiczna. Reprinted in Blaustein, L. (2005). Wybór pism estetycznych (pp. 3-19). Z. Rosińska (Ed.). Krakow: TAiWPN Universitas.

Blaustein, L. (1938b). O percepcji stuchowiska radiowego. Warsaw: Polskie Radio Biuro Studiów. Partly reprinted in Blaustein, L. (2005). Wybór pism estetycznych (pp. 145-196). Z. Rosińska (Ed.). Krakow: TAiWPN Universitas.

Blaustein, L. (1939). Étude sur la perceptron des pièces radiophoniques. Kwartalnik Psychologiczny, 11, $105-161$.

Bostar, L. (1994). Reading Ingarden read Husserl: Metaphysics, ontology, and phenomenological method. Husserl Studies, 10, 211-236.

Brentano, F. (1874). Psychologie vom empirischen Standpunkte. Berlin: Duncker \& Humblot. English trans. Antos C. Rancurello, D.B. Terrell, Linda L. McAlister. In Brentano, F. (1995b). Psychology from an empirical standpoint. London: Routledge.

Brentano, F. (1982). Deskriptive Psychologie. Hamburg: Felix Meiner. English trans. Benito Müller. In Brentano, F. (1995a). Descriptive psychology. London: Routledge.

Brożek, A. (2011). Kazimierz Twardowski. Die Wiener Jahre. Wien: Springer-Verlag. https://doi. org/10.1007/978-3-7091-0771-3.

Cavallin, J. (1997). Content and object: Husserl, Twardowski and Psychologism. Dordrecht-Boston-London: Kluwer Academic Publishers.

Chrudzimski, A. (1996). W sprawie Ingardenowskiej koncepcji intuicji przeżywania. Principia, 15, 137-152.

Chrudzimski, A. (1999). Die Erkenntnistheorie von Roman Ingarden. Dordrecht: Kluwer Academic Publishers.

Chrudzimski, A. (2001). Intentionalitätstheorie beim frühen Brentano. Dordrecht: Kluwer Academic Publishers.

Chrudzimski, A., \& Łukasiewicz, D. (Eds.). (2006). Actions, products, and things. Brentano and Polish philosophy. Frankfurt: Ontos Verlag.

Curvello, F. V. (2016). Franz Brentano's mereology and the principles of descriptive psychology. Dialogue and Universalism, 26(3), 109-123.

Czerny, J. (1987). Brentanizm i jego recepcja w filozofii europejskiej. Katowice: Uniwersytet Ślaski.

Dąmbska, I. (1978). François Brentano et la pensée philosophique en Pologne. Casimir Twardowski et son école. Grazer Philosophische Studien, 5, 117-129. https://doi.org/10.5840/gps1978524.

De Boer, T. (1978). The development of Husserl's thought. The Hague-Boston-London: Martinus Nijhoff.

Dewalque, A. (2013). Brentano and the parts of the mental: A mereological approach to phenomenal intentionality. Phenomenology and the Cognitive Sciences, 12(3), 447-464. https://doi.org/10.1007/s11097-012-9293-8.

Feest, U. (2014). The continuing relevance of nineteenth-century philosophy of psychology: Brentano and the autonomy of psychological methods. In M. C. Galavotti, D. Dieks, W. J. Gonzalez, S. Hartmann, T. Uebel, \& M. Weber (Eds.), New directions in the philosophy of science (pp. 693-709). ChamHeidelberg-New York-Dordrecht-London: Springer.

Fisette, D. (2018). Phenomenology and descriptive psychology: Brentano, Stumpf, Husserl. In D. Zahavi (Ed.), The Oxford handbook of the history of phenomenology (pp. 88-104). Oxford: Oxford University Press.

Głombik, C. (1999a). Bronisław Bandrowski i jego związki z getyngeńskim seminarium. Lingua ac Communitas, 9, 127-138.

Głombik, C. (1999b). Husserl i Polacy. Pierwsze spotkania, wczesne reakcje. Katowice: Gnome. German trans. Christoph Schatt. In Głombik, C. (2011). Husserl und die Polen. Frühgeschichte einer Rezeption. Würzburg: Königshausen \& Neumann.

Głombik, C. (1999c). O niedoszłych polskich przekładach Logische Untersuchungen. In W. Tyburski and R. Wiśniewski (Eds.), Polska filozofia analityczna. W kregu szkoły Lwowsko-Warszawskiej (pp. 89-106). Toruń: Wydawnictwo Uniwersytetu Toruńskiego.

Husserl, E. (1984a). Logische Untersuchungen. Zweiter Band. Erster Teil. Untersuchungen zur Phänomenologie und Theorie der Erkenntnis. In U. Panzer (Ed.), Husserliana: Edmund Husserl Gesammelte Werke, vol. 19/1. The Hague-Boston-Lancaster: Kluwer Academic Publishers.

Husserl, E. (1984b). Logische Untersuchungen. Zweiter Band. Zweiter Teil. Elemente einer phänomenologischen Aufklärung der Erkenntnis. In U. Panzer (Ed.), Husserliana: Edmund Husserl Gesammelte Werke, vol. 19/2. The Hague-Boston-Lancaster: Kluwer Academic Publishers.

Husserl, E. (1987). Erinnerungen an Franz Brentano (1919). In Husserl, E. Aufsätze und Vorträge (19111921) (pp. 304-315). In T. Nenon \& H. R. Sepp (Eds.), Husserliana: Edmund Husserl Gesammelte Werke, vol. 25. Dordrecht-Boston-Lancaster: Martinus Nijhoff.

Husserl, E. (1994). In K. Schuhmann \& E. Schuhmann (Eds.), Briefwechsel. Bd. III. Die Göttinger Schule. Dordrecht: Kluwer Academic Publishers. 
Husserl, E. (2012). Zur Lehre vom Wesen und zur Methode der eidetischen Variation. Texte aus dem Nachlass (1891-1935). In D. Fonfara (Ed.), Husserliana: Edmund Husserl Gesammelte Werke, (vol. 41). Dordrecht: Springer.

Ingarden, R. (1915). Review of the second edition of Husserl's Logische Untersuchungen. Przeglad Filozoficzny, 18(3-4): 305-311. English trans. Arthur Szylewicz. In Szylewicz, A. (1993). Roman Ingarden's review of the second edition of Husserl's Logical Investigations. Husserl Studies, 10: 1-12.

Ingarden, R. (1919a). Dążenia fenomenologów. Przegląd Filozoficzny, 22(3), 118-156.

Ingarden, R. (1919b). Dążenia fenomenologów (Dokończenie). Przegląd Filozoficzny, 22(4), 315-351.

Ingarden, R. (1921). Über die Gefahr einer Petitio Principii in der Erkenntnistheorie. Jahrbuch für Philosophie und phänomenologische Forschung, 4, 545-568.

Ingarden, R. (1922). W sprawie "istoty doświadczenia wewnętrznego.” Przegląd Filozoficzny, 25(4), $512-534$.

Ingarden, R. (1934a). Edmund Husserl: twórca fenomenologji. Wiadomości Literackie, 11(41), 4.

Ingarden, R. (1934b). Niektóre sprawy sporne we współczesnej psychologji. Marcholt, 1(1), 34-50.

Ingarden, R. (1934c). Review of Witwicki's Psychology. Przyjaciel Szkoty, 13(1-2), 61-62.

Ingarden, R. (1937). Wandlungen der philosophischen Atmosphäre in Polen. Slavische Rundschau, 9, $224-233$.

Ingarden, R. (1938). Działalność naukowa Kazimierza Twardowskiego. In Kazimierz Twardowski. Nauczyciel-Uczony-Obywatel (pp. 13-30). Lvov: Polskie Towarzystwo Filozoficzne.

Ingarden, R. (1963). Filozofia w rozumieniu Brentany. In Ingarden, R. Z badań nad filozofia wspótczesna (pp. 195-249). Warsaw: Państwowe Wydawnictwo Naukowe. German trans. Włodzimierz Galewicz. In Ingarden, R. (1999). Schriften zur frühen Phänomenologie (pp. 1-52). W. Galewicz (Ed.). Tübingen: Niemeyer. https://doi.org/10.1515/9783110916195.1.

Ingarden, R. (1966). Uwagi o niektórych twierdzeniach ontologicznych w książce Kazimierza Twardowskiego pt. Zur Lehre vom Inhalt und Gegenstand der Vorstellungen. Ruch Filozoficzny, 25(1-2), 21-35. German trans. Włodzimierz Galewicz. In Ingarden, R. (1999). Schriften zur frühen Phänomenologie (pp. 69-91). W. Galewicz (Ed.). Tübingen: Niemeyer. https://doi.org/10.1515/9783110916195.69.

Ingarden, R. (1975). On the motives which led Husserl to transcendental idealism. English trans. Arnór Hannibalsson. The Hague: Martinus Nijhoff.

Ingarden, R. (1994). Über die Stellung der Erkenntnistheorie im System der Philosophie. In Ingarden, R. Frühe Schriften zur Erkenntnistheorie (pp. 277-309). W. Galewicz (Ed.). Tübingen: Niemeyer.

Ingarden, R. (1998). Meine Erinnerungen an Edmund Husserl (1968). In Ingarden, R. Schriften zur Phänomenologie Edmund Husserls (pp. 400-430). W. Galewicz (Ed.). Tübingen: Niemeyer. https://doi. org/10.1515/9783110916416.400.

Jadacki, J. (2009). Polish analytical philosophy: Studies on its heritage. Warsaw: Semper.

Jadczak, R. (1993). Uczeń i nauczyciel: Z listów Leopolda Blausteina do Kazimierza Twardowskiego z lat 1927-1930. In J. J. Jadacki and B. Markiewicz (Eds.), ...a Madrości zło nie przemoże (pp. 19-27). Warsaw: Polskie Towarzystwo Filozoficzne.

Jadczak, R. (1995). Powstanie filozofii analitycznej w Polsce (noty bibliograficzne). Toruń: Wydawnictwo Adam Marszałek.

Jadczak, R. (1997). Mistrz i jego uczniowie. Warsaw: Scholar.

Kleszcz, R. (2006). Twardowski a problem psychologizmu. Studia z Filozofii Polskiej, 1, 13-26.

Kriegel, U. (2018). Brentano's philosophical system: Mind, being, value. Oxford: Oxford University Press.

Kuliniak, R., Leszczyna, D., \& Pandura, M. (2016). Wstęp. In Ingarden, R. Korespondencja Romana Witolda Ingardena z Kazimierzem Twardowskim (pp. 5-151). R. Kuliniak, D. Leszczyna and M. Pandura (Eds.). Kęty: Wydawnictwo Marek Derewiecki.

Libardi, M. (1996). Franz Brentano (1838-1917). In L. Albertazzi, M. Libardi, \& R. Poli (Eds.), The school of Franz Brentano (pp. 25-79). Dordrecht: Kluwer Academic Publishers.

Luft, S. (2012). Husserl's method of reduction. In S. Luft and S. Overgaard (Eds.), The Routledge companion to phenomenology (pp. 243-253). London-New York: Routledge.

Łukasiewicz, J. (1906). Analiza i konstrukcja pojęcia przyczyny. Przegląd Filozoficzny, 9(2), 105-179.

Łukasiewicz, D. (2009). Polish metaphysics and the Brentanian tradition. In S. Lapointe, J. Woleński, M. Marion and W. Miskiewicz (Eds.), The golden age of Polish philosophy. Kazimierz Twardowski's philosophical legacy (pp. 19-31). Dordrecht: Springer.

Mill, J. S. (1843). System of logic, ratiocinative and inductive, being a connected view of the principles of evidence, and the methods of scientific investigation (Vol. 2). London: John W. Parker.

Miskiewicz, W. (2003). Réalisme gnoséologique contre réalizme sceptique; Ingarden et la reception de Brentano en Pologne. Les Études philosophiques, 64(1), 83-97.

Miskiewicz, W. (2009). Leopold Blaustein's analytical phenomenology. In S. Lapointe, J. Woleński, M. Marion and W. Miskiewicz (Eds.), The golden age of Polish philosophy: Kazimierz Twardowski's philosophical legacy (pp. 181-188). Dordrecht: Springer. 
Mulligan, K., \& Smith, B. (1985). Franz Brentano on the ontology of mind. Philosophy and Phenomenological Research, 45(4), 627-644.

Paczkowska-Łagowska, E. (1980). Psychika i poznanie. Epistemologia Kazimierza Twardowskiego. Warsaw: Państwowe Wydawnictwo Naukowe.

Płotka, W. (2017). Early phenomenology in Poland (1895-1945): Origins, development, and breakdown. Studies in East European Thought, 69(1), 79-91. https://doi.org/10.1007/s11212-017-9274-0.

Pokropski, M. (2015). Leopold Blaustein's critique of Husserl's early theory of intentional act, object and content. Studia Phaenomenologica, 15, 93-103. https://doi.org/10.5840/studphaen2015156.

Poli, R. (1996). Kazimierz Twardowski (1866-1938). In L. Albertazzi, M. Libardi, \& R. Poli (Eds.), The school of Franz Brentano (pp. 207-231). Dordrecht: Kluwer Academic Publishers.

Rizzoli, L. (2008). Erkenntnis und Reduktion. Die operative Entfaltung der phänomenologischen Reduktion im Denken Edmund Husserls. Dordrecht: Springer.

Rollinger, R. (1999). Husserl's position in the school of Brentano. Dordrecht-Boston-London: Kluwer Academic Publishers.

Rollinger, R. D. (2012). Brentano's Psychology from an empirical standpoint: Its background and conception. In I. Tănăsescu (Ed.), Franz Brentano's metaphysics and psychology. Upon the sesquicentennial of Franz. Brentano's dissertation (pp. 261-309). Bucharest: Zeta Books.

Rosiak, M. (1998). Twardowski and Husserl on wholes and parts. In K. Kijania-Placek \& J. Woleński (Eds.), The Lvov-Warsaw school and contemporary philosophy (pp. 85-100). Dordrecht: Kluwer Academic Publishers.

Rzepa, T. (1991). Psychologia Władysława Witwickiego. Poznań: Wydawnictwo Naukowe UAM.

Rzepa, T. (1999). Władysława Witwickiego psychologia zaprzepaszczonych szans. Filozofia Nauki, 7(3-4), 119-130.

Rzepa, T. (2002). O intepretowaniu psychologicznym w kregu Szkoły Lwowsko-Warszawskiej. Warsaw: Polskie Towarzystwo Semiotyczne.

Rzepa, T., \& Stachowski, R. (1993). Roots of the methodology of Polish psychology. In F. Coniglione, R. Poli, \& J. Wolenski (Eds.), Polish scientific philosophy: The Lvov-Warsaw School (pp. 233-250). AmsterdamAtlanta: Rodopi.

Schuhmann, K. (1993). Husserl and Twardowski. Poznan Studies in the Philosophy of the Sciences and the Humanities, 28, 41-58.

Seron, D. (2017). Brentano's project of descriptive psychology. In U. Kriegel (Ed.), The Routledge handbook of Franz Brentano and the Brentano school (pp. 35-40). New York: Routledge.

Smith, B. (1994). Austrian philosophy. In The legacy of Franz Brentano. Chicago-LaSalle: Open Court Publishing Company.

Sowa, R. (2007). Essences and eidetic laws in Edmund Husserl's descriptive eidetics. New Yearbook for Phenomenology and Phenomenological Philosophy, 7, 77-108.

Sowa, R. (2012). Eidetics and its methodology. English trans. Elizabeth A. Behnke. In S. Luft \& S. Overgaard (Eds.), The Routledge companion to phenomenology (pp. 254-265). London-New York, Routledge.

Surma, P. (2016). Bronisław Bandrowski. A disrupted thread in Polish analytical thought. In A. Brożek, A. Chybińska, J. Jadacki, \& J. Woliński (Eds.), Tradition of the Lvov-Warsaw School: Ideas and continuations (pp. 265-278). Leiden: Brill, Rodopi.

Twardowski, K. (1894). Zur Lehre vom Inhalt und Gegenstand der Vorstellungen. Eine Psychologische Untersuchung. Vienna: Hölder. English trans. Reinhardt Grossmann. In Twardowski, K. (1977). On the content and object of presentations. A psychological investigation. The Hague: Martinus Nijhoff.

Twardowski, K. (1903). Ankieta w sprawie nauczania propedeutyki filozoficznej w gimnazjach. Przeglad Filozoficzny, 6(1), 111-113.

Twardowski, K. (1965). Wybrane pisma filozoficzne. Warsaw: Państwowe Wydawnictwo Naukowe.

Twardowski, K. (1991). Selbstdarstellung. Grazer Philosophische Studien, 39, 1-24. https://doi.org/10.1163 /18756735-90000458. English trans. Arthur Szylewicz. In Twardowski, K. 1999. On actions, products and other topics in philosophy (pp. 17-31). J. L. Brandl, J. Woleński (Eds.). Amsterdam: Rodopi.

Twardowski, K. (1992). Psychologia pożądań i woli. In Twardowski, K. Wybór pism psychologicznych $i$ pedagogicznych (pp. 203-248). Warsaw: Wydawnictwa Szkolne i Pedagogiczne.

Twardowski, K. (1999). On actions, products and other topics in philosophy. J. L. Brandl \& J. Woleński (Eds.). Amsterdam: Rodopi.

Twardowski, K. (2016). Logik. Wiener Logikkolleg 1894/95. A. Betti \& V. Raspa (Eds.). Berlin-Boston: Walter de Gruyter.

Van der Schaar, M. (2015). Kazimierz Twardowski: A Grammar for Philosophy. Leiden: Brill.

Varga, P. A. (2016). The Impersonalien controversy in early phenomenology. Sigwart and the school of Brentano. Brentano Studien, 14, 229-280. 
Wallner, I. M. (1987). In defense of Husserl's transcendental idealism: Roman Ingarden's critique reexamined. Husserl Studies, 4, 3-43.

Witwicki, W. (1900). Analiza psychologiczna ambicji. Przeglad Filozoficzny, 3(4), 26-49.

Witwicki, W. (1904). Analiza psychologiczna objawów woli. Lvov: Towarzystwo dla Popierania Nauki Polskiej.

Witwicki, W. (1912). W sprawie przedmiotu i podziału psychologii. Lvov: Skład główny w Księgarni Gubrynowicza i Syna we Lwowie.

Witwicki, W. (1925). Psychologja. Dla użytku stuchaczów wyższych zakładów naukowych (Vol. 1). LvovWarsaw-Krakow: Wydawnictwo Zakładu Narodowego im. Ossolińskich.

Witwicki, W. (1931). O stosunku treści do przedmiotu przedstawienia. In Księa pamiątkowa Polskiego Towarzystwa Filozoficznego we Lwowie. 12 II 1904-12 II 1929 (pp. 394-412). Lvov: Polskie Towarzystwo Filozoficzne.

Woleński, J. (1989). Logic and philosophy in the Lvov-Warsaw School. Dordrecht: Kluwer Academic Publishers.

Woleński, J. (2017). Brentanian motives in Kazimierz Twardowski and his students. In A. Brożek, F. Stadler, \& J. Woleński (Eds.), The significance of the Lvov-Warsaw School in the European culture (pp. 47-64). Vienna Circle Institute Yearbook (Vol. 21). Dordrecht: Springer. https://doi.org/10.1007/978-3-31952869-4 4 .

Zahavi, D. (2004). Back to Brentano? Journal of Consciousness Studies, 11(10-11), 66-87.

Zahavi, D. (2017). Husserl's legacy: Phenomenology, metaphysics, and transcendental philosophy. Oxford: Oxford University Press.

Publisher's note Springer Nature remains neutral with regard to jurisdictional claims in published maps and institutional affiliations. 